\title{
ANALISIS PENGGUNAAN INTERNET TERHADAP MORAL KNOWING TENTANG NARKOTIKA PADA SISWA MENENGAH PERTAMA
}

\author{
Ika Chastanti ${ }^{1 *}$, Indra Kumalasari Munthe ${ }^{2}$ \\ ${ }^{1 *}$ Pendidikan Biologi STKIP Labuhan Batu, Jalan SM. Raja Aek Tapa Rantauprapat Sumatera Utara \\ Indonesia \\ ${ }^{2}$ Ilmu Hukum STKIP Labuhan Batu, Jalan SM. Raja Aek Tapa Rantauprapat Sumatera Utara Indonesia \\ *email: chastanti.ika@gmail.com
}

\section{Received: 12 Maret 2019 Accepted: 1 Juni 2019 Published: 30 Juni 2019}

\begin{abstract}
Abstrak
Tujuan penelitian ini adalah untuk mengetahui pengaruh penggunaan internet terhadap moral knowing siswa tentang narkotika. Teknik sampling dalam penelitian adalah purposive sampling. Teknik pengumpulan data dilakukan dengan melakukan in-depth interview dan memberikan kuesioner kepada siswa kemudian data dianalisis secara kualitatif dengan menggunakan model Miles dan Hubeman. Hasil penelitian menunjukkan bahwa penggunaan internet di kalangan siswa belum dilakukan dengan baik karena siswa belum bisa memanfaatkan internet dengan fungsi sarana pembelajaran maupun fungsi hiburan. Siswa memanfaatkan internet untuk mengakses media sosial (54\%), belajar (25\%), game online $(8 \%)$, hiburan (11\%), dan online shop (2\%), sehingga moral knowing siswa tentang narkotika tergolong rendah.
\end{abstract}

Kata kunci: internet, moral knowing, narkotika

\begin{abstract}
The purpose of this study was to determine the effect of internet usage on students' moral knowing about narcotics. The sampling technique in the study was purposive sampling. Data collection techniques are carried out by conducting In-depth interviews and questionnaires to students, then the data are analyzed qualitatively using Miles and Huberman models. The results of the study show that internet usage among students has not been done well because students have not been able to use the internet with the functions of learning facilities and entertainment functions. Students use the internet to access social media (54\%), study (25\%), online games (8\%), entertainment (11\%), and online shops (2\%) so that the moral knowledge of students about narcotics is low.
\end{abstract}

Keywords: internet, moral knowing, narcotics

(C) 2019 LPPM IKIP PGRI Pontianak, Indonesia

\section{PENDAHULUAN}

Internet sebagai sebuah jaringan besar yang menghubungkan jaringan komputer baik dari organisasi bisnis, organisasi pemerintahan, dan sekolah-sekolah dari seluruh dunia secara langsung dan cepat (Turban et. al., 2005). Penggunaan internet saat ini dapat diakses oleh semua usia baik anak-anak maupun dewasa. Tingkat penggunaan internet di seluruh dunia berdasarkan 
usia sebanyak 93\% dimanfaatkan oleh remaja (12-17 tahun) dan dewasa (18-29 tahun), 7\% dimanfaatkan oleh dewasa (30-65 tahun) (Sherlyanita \& Aini, 2016). Kemenkominfo Republik Indonesia, di Indonesia sendiri 80 persen di antaranya terdiri dari remaja 15-19 tahun dan pada kenyataannya, remaja menggunakan internet bukan hanya untuk kebutuhan edukasi saja, melainkan dipergunakan juga untuk hiburan, belanja, media sosial dan lain sebagainya (Noviandari, 2015).

Digitalisasi bahkan telah diimplementasikan pada institusi pendidikan di negara-negara berkembang di seluruh dunia, seperti pengajaran menggunakan presentasi digital, pengumpulan tugas secara online dan lain sebagainya. Siswa maupun pengajar secara tidak langsung dituntut untuk menguasai berbagai alat maupun perangkat lunak teknologi informasi mengingat perangkat keras dan perangkat lunak tersebut sebagai fondasi dari berjalannya sebuah teknologi informasi (Sherlyanita \& Aini, 2016).

Keunggulan dan kelebihan dari internet yang seharusnya digunakan untuk membangun pondasi keilmuan di sekolah, seakan sirna manakala kita melihat anak bangsa justru terseret dalam berbagai problema yang berawal dari penggunaan media sosial yang tidak terkontrol. Pergaulan bebas, pemakaian obat terlarang, bahasa alay, dan budaya acuh seakan menjadi hal biasa dan lumrah dikalangan generasi muda (Siregar, 2004). Internet saat ini memegang peranan penting dan strategis dalam menyampaikan bahaya penyalahgunaan narkotika kepada masyarakat, khususnya generasi muda yang rentan terhadap penyalahgunaan narkoba, dengan diperolehnya informasi tersebut diharapkan generasi muda paham dan mengerti tentang bahaya narkotika bagi kesehatan dan lingkungan sekitar.

Pendidikan karakter merupakan salah satu cara yang dapat digunakan untuk memberikan perubahan yang besar dalam dunia pendidikan. Menumbuhkan pendidikan karakter dibutuhkan usaha yang maksimal dari semua pihak baik itu keluarga, sekolah, dan juga lingkungan. Persoalan karakter merupakan masalah terbesar yang tejadi pada anak bangsa, terutama dari aspek generasi muda yang sekarang ini dihadapkan pada situasi dan kondisi akibat terpaan globalisasi (Marviana, 2000).

Pendidikan karakter dapat dimaknai sebagai pendidikan budi pekerti, pendidikan moral, pendidikan nilai, pendidikan watak, yang bertujuan untuk mengembangkan kemampuan peserta didik dalam menentukan baik dan buruk, memelihara apa yang baik, dan mengaplikasikan kebaikan tersebut dalam kehidupan sehari-hari (Cahyo, 2017). Sekolah memiliki tanggung jawab 
moral untuk mendidik siswa menjadi pintar dan memiliki karakter. Tugas sekolah tidak hanya mengajar, tetapi juga mendidik sehingga siswa tidak hanya memiliki kemampuan kognitif tetapi juga memiliki karakter yang baik. Pendidikan karakter bukan hanya sekedar mengajarkan mana yang benar dan mana yang salah, akan tetapi lebih dari itu pendidikan karakter adalah usaha menanamkan kebiasaan-kebiasaan yang baik (habituation) sehingga peserta didik mampu bersikap dan bertindak berdasarkan nilai-nilai yang telah menjadi kepribadiannya, dengan kata lain, pendidikan karakter yang baik harus melibatkan pengetahuan yang baik (moral knowing), perasaan yang baik atau loving good (moral feeling) dan perilaku yang baik (moral action) sehingga terbentuk perwujudan kesatuan perilaku dan sikap hidup peserta didik (Anonim, 2011).

Moral knowing merupakan hal penting untuk diajarkan, setelah anak memiliki pengetahuan moral (moral knowing), orang tua hendaknya dapat menumbuhkan rasa atau keinginan anak untuk berbuat baik (desiring the good). Pada sisi lain, keinginan untuk berbuat baik bersumber dari kecintaan untuk berbuat baik. Aspek kecintaan ini sebagai sumber energi yang secara efektif membuat seseorang mempunyai karakter yang konsisten antara pengetahuan (moral knowing) dan tindakannya (moral action). Oleh karena itu, aspek ini merupakan yang paling sulit untuk diajarkan karena menyangkut wilayah emosi (otak kanan) (Muslich, 2011).

Internet menyediakan berbagai informasi yang bermanfaat bagi masyarakat, sehingga internet dapat dijadikan sebagai sumber informasi yang paling mudah, cepat, dan luas. Salah satu konten bermanfaat yang bisa dicari melalui internet adalah pemahaman mengenai narkotika, mulai dari jenis narkotika, bahaya narkotika bagi kesehatan, dan tindakan pidana bagi penyalahguna narkotika. Seiring dengan semakin banyaknya jumlah penyalahguna narkotika di kalangan siswa menengah pertama, maka dibutuhkan pemahaman mengenai narkotika yang bisa diakses dengan menggunakan internet. Berdasarkan wawancara dengan siswa menengah pertama diperoleh bahwa siswa membawa smartphone ke sekolah. Siswa menggunakan fasilitas internet ketika jam istirahat. Siswa biasanya membuka akun Facebook untuk melihat status terkini dari temannya, mengakses Google untuk mencari informasi tentang materi pelajaran, untuk melihat video ataupun musik siswa mengakses Youtube dan membuka akun Instagram untuk melihat online shop. Siswa biasanya mengakses internet lebih dari 3 kali dalam sehari. Siswa menggunakan fasilitas internet selain untuk kebutuhan edukasi, tetapi dipergunakan juga untuk hiburan, belanja, media sosial dan lain sebagainya, oleh karena itu tujuan penelitian ini adalah untuk mengetahui penggunaan internet terhadap pengetahuan moral siswa tentang narkotika. 


\section{METODE}

Penelitian ini merupakan deskriptif kualitatif. Data primer merupakan sumber data utama dalam penelitian ini dengan melakukan wawancara mendalam (In-depth Interview) kepada siswa. Data sekunder menggunakan kuesioner untuk mengetahui pemahaman siswa tentang narkotika melalui pemanfaatan internet. Penelitian ini dilaksanakan di SMP Negeri 1 Kulauh Hulu. Jumlah sampel dalam penelitian ini sebanyak 66 orang siswa. Teknik Sampling menggunakan Purposive Sampling. Teknik analisis data dilakukan dalam 3 tahap: (1) Reduksi data yaitu (a) meringkaskan data kontak langsung dengan orang, kejadian dan situasi di lokasi penelitian, (b) pengkodean, (c) pembuatan catatan objetif, (d) membuat catatan reflektif, (e) membuat catatan marginal, (f) penyimpana data, (g) pembuatan memo, (h) analisis antarlokasi, dan (i) pembuatan ringkasan sementara antar lokasi. (2) Display data dengan menyusun teks naratif, dan (3) Verifikasi yaitu tahap penarikan kesimpulan.

\section{HASIL DAN PEMBAHASAN}

Hasil analisis kuesioner yang diberikan kepada siswa tentang penggunaan internet disajikan pada Gambar 1. Diperoleh bahwa sebesar 54\% siswa memanfaatkan untuk media social, sarana belajar (25\%), game online (8\%), hiburan (11\%), dan online shop (2\%).

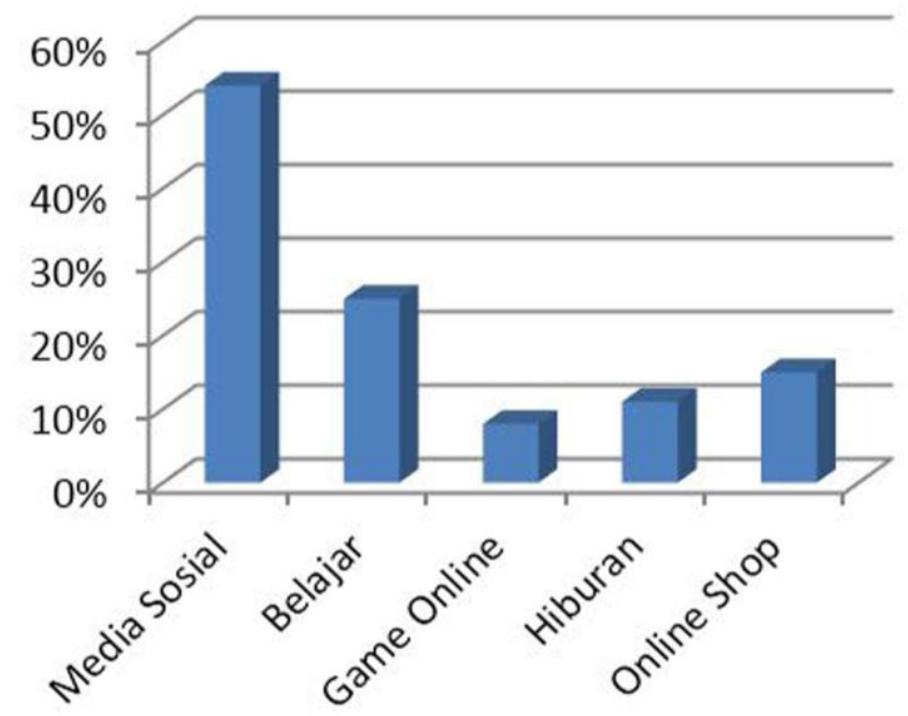

Gambar 1. Grafik Penggunaan Internet oleh Siswa 
Hasil penelitian menunjukkan bahwa penggunaan internet yang banyak diakses siswa adalah media sosial (54\%). Hasil wawancara kepada siswa diperoleh bahwa media sosial yang diakses siswa yaitu Facebook, Instagram, Whastapp, dan Line. Siswa menggunakan internet untuk belajar jika mendapatkan pekerjaan rumah dari guru karena siswa mengaku malas mencari jawaban dengan menggunakan buku. Game online yang biasa dimainkan siswa adalah Mobile Legend, pada hiburan siswa biasanya unduh video melalui Youtube dan membaca berita tentang selebritis indonesia, serta online shop hanya siswa tertentu saja yang suka belanja online. Penelitian mengenai penggunaan internet oleh kalangan siswa (13-17 tahun), media sosial memiliki pengaruh besar dalam penggunaan internet bagi siswa yaitu meningkatnya aktivitas siswa untuk mengakses situs media sosial, mengirimkan pesan singkat, melakukan panggilan video, menulis dan mengirim komentar dalam akun media sosial seperti Twitter, Facebook, Instagram. Media sosial dengan penetrasi tinggi di Indonesia ditempati oleh Facebook dengan presentase pengguna 14\% dari keseluruhan pengguna, kemudian disusul dengan WhatsApp, Twitter, Facebook Messenger, Google+, LinkedIn, Instagram, Skype, dan Pinterest dan urutan terakhir ditempati Line dengan presentase 6\% (Sherlyanita dan Aini, 2016).

Hasil analisis penggunaan internet yang diakses siswa sebagai sarana belajar mengenai narkotika (Gambar 2) dibagi dalam 4 item yaitu (1) Jenis narkotika; (2) Kegunaan narkotika; (3) Dampak buruk narkotika; dan (4) Ancaman hukuman bagi penyalahguna narkotika.

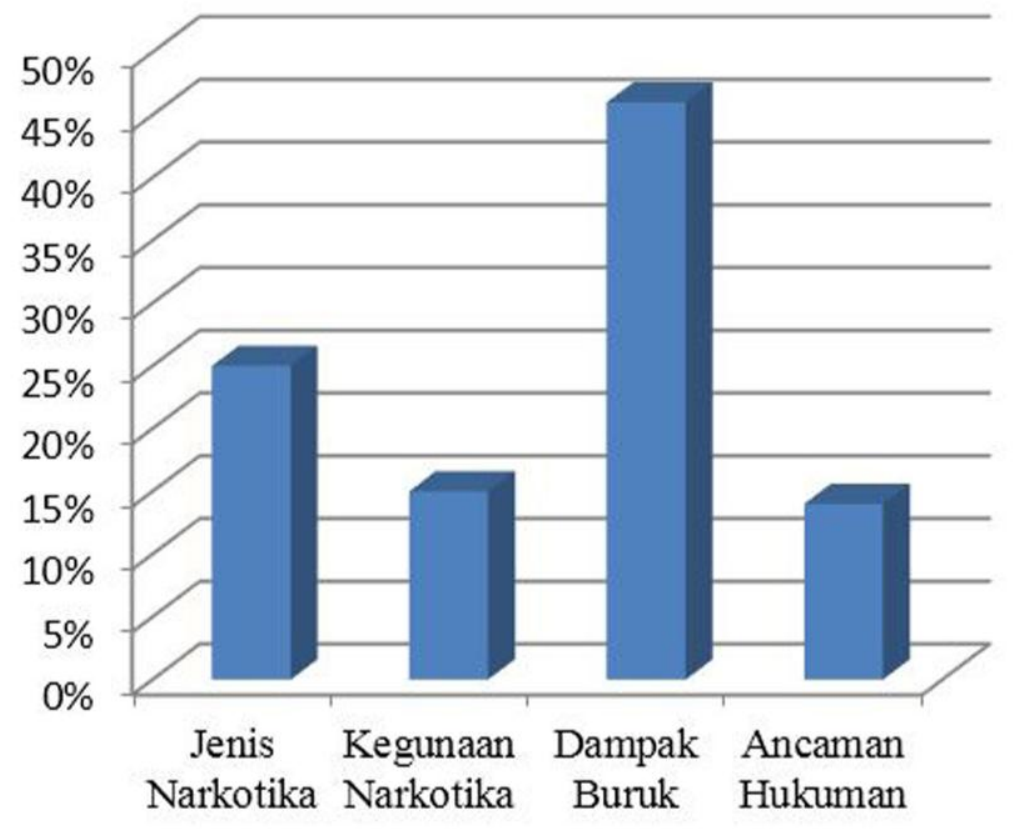

Gambar 2. Grafik Moral Knowing Siswa Tentang Narkotika 
Hasil penelitian menunjukkan bahwa moral knowing siswa tentang narkotika masih rendah pada pengetahuan jenis narkotika (24\%), siswa tidak mengetahui golongan narkotika dan jenis narkotika yang siswa ketahui hanyalah ganja. Narkotika mempunyai 3 golongan yaitu : (1) Golongan I yaitu jenis narkotika yang secara umum dikenal oleh masyarakat antara lain ganja, shabu-shabu, kokain, heroin, opium; (2) Golongan II yaitu jenis narkotika seperti morfin, pertidin, dan lain-lain; (3) Golongan III yaitu jenis narkotika seperti kodein, dan lain-lain. Pengetahuan siswa mengenai kegunaan narkotika (15\%), siswa tidak memahami tentang kegunaan narkotika dalam medis dan pengobatan. Narkotika dapat digunakan dengan cara yang diatur oleh Undang-Undang. Narkotika juga dapat digunakan untuk penelitian, pendidikan, dan medis (pengobatan). Pengetahuan mengenai Dampak buruk narkotika (46\%), pada aspek ini siswa sudah memahami mengenai dampak buruk narkotika bagi kesehatan, salah satu dampaknya adalah dapat merusak syaraf tubuh. Kandungan yang terdapat pada narkotika memang bisa memberikan dampak negatif jika disalahgunakan. Dampak narkotika bagi tubuh adalah (1) Dehidrasi karena bisa menyebabkan keseimbangan elektrolit berkurang sehingga badan akan kekurangan cairan dan menyebabkan kejang-kejang; (2) Halusinasi, jika penggunaan sudah terlalu lama maka akan mengakibatkan depresi serta kecemasan terus menerus; (3) Menurunnya tingkat kesadaran, jika digunakan dalam dosis berlebih maka akan membuat tubuh semakin rileks sehingga kesadaran berkurang drastic; (4) Kematian, jika digunakan dalam dosis tinggi maka akan menyebabkan kejang dan menimbulkan kematian; dan (5) Gangguan kualitas hidup, biasanya akan sulit konsentrasi saat bekerja (Juliana, 2013). Pengetahuan siswa mengenai ancaman hukuman bagi penyalahguna narkotika diperoleh sebesar 14\% siswa sudah memahami sedikit mengenai penyalahguna narkotika, hukuman pidana bagi pelakunya. Sebenarnya sudah jelas diatur dalam Undang-Undang mengenai jenis-jenis narkotika yang dilarang diproduksi, dijual, atau digunakan tanpa izin dari pihak yang berwenang. Sanksi pidana dalam Undang Undang Narkotika Nomor 25 Tahun 2009 sudah diatur dalam Pasal 111, 112, 113, 114 Jo 132, Pasal 127 (Kitab Undang-Undang Narkotika).

Media komunikasi memegang peranan penting dalam menyampaikan bahaya penyalahgunaan narkotika kepada masyarakat, khususnya kepada generasi muda yang rentan terhadap penyalahgunaan narkotika, dengan diperolehnya informasi tersebut, generasi muda diharapkan paham dan mengerti mengenai bahaya narkotika bagi dirinya dan lingkungan sekitarnya. Media komunikasi telah menjadi sarana bagi seseorang untuk menyaksikan berbagai 
peristiwa dalam waktu cepat. Informasi tentang narkotika juga bisa dengan mudah diakses melalui media, baik media konvensional, media massa, maupun media baru yang berbasis teknologi informasi dan komunikasi, apa yang diperoleh dari media merupakan wahana pembelajaran yang potensial dalam meningkatkan kapasitas pribadi dan masyarakat, sehingga media menjadi wahana edukasi public yang efektif, sehingga potensi penyalahgunaan dan pengedaran narkotika dapat teratasi dengan baik ( Hastjarjo, 2011).

Konteks media sosial di era digital sangat penting karena akan menentukan efektifitas media sosial dalam pembentukan karakter. Hasil wawancara yang dilakukan kepada siswa menunjukkan bahwa rata-rata penggunaan internet dilakukan hampir setiap hari dalam waktu seminggu. Siswa aktif menggunakan internet untuk mengakses media social. Hasil wawancara yang dilakukan kepada guru menunjukkan bahwa banyak siswa ketika pembelajaran sering mengakses internet untuk menjawab pertanyaan yang diberikan oleh guru dan juga untuk update status di media social.

Indonesia merupakan salah satu negara tertinggi pengguna internet di seluruh dunia (emarketer.com), oleh karena tidak mengherankan bila semua orang dapat mengakses informasi dimanapun dan kapanpun, hingga kini persebaran narkotika sudah hampir tidak bisa dicegah. Dengan adanya internet semakin memudahkan menawarkan narkotika dengan lebih aman dan transaksi dapat dilakukan dengan cepat, mudah, dan aman. Informasi tentang narkotika dengan mudah bisa diakses melalui media. Tetapi sayangnya, teknologi ini tidak dimanfaatkan guru dengan baik untuk mempermudah memberikan informasi tentang narkotika kepada siswa. Guru dituntut untuk mampu mengembangkan kemajuan teknologi seperti internet dalam pembelajaran, Guru misalnya membuat blog khusus tentang narkotika dan berbagi postingan tentang narkotika di media social siswa. Dengan bantuan internet dan media-media sosial, mengorganisir dan mengerahkan massa tidak lagi membutuhkan biaya yang besar (meskipun mungkin tidak bisa dikatakan tanpa biaya samasekali). Oleh sebab itulah saat ini dapat kita jumpai dengan mudah berbagai bentuk penggalangan solidaritas dan massa melalui media sosial, seperti melalui Facebook, Twitter, dan lain sebagainya, antara lain Bincang Edukasi (bincangedukasi.com), Indonesia Mengajar (indonesiamengajar.org) (Siregar, 2004).

Media sosial juga dapat digunakan untuk media belajar. Individu yang memiliki minat terhadap sesuatu dapat membentuk kelompok di jejaring sosial. Mereka dapat saling bertukar pikiran dan belajar tanpa harus ada hubungan tatap muka. Dengan pemanfaatan media sosial 
seperti ini, ilmu pengetahuan akan berkembang lebih cepat. (Suharko, 2006). Secara keseluruhan media komunikasi berperan memperluas kemampuan interaksi diantara anggota masyarakat. Dengan demikian media komunikasi yang berkualitas akan bisa berperan dalam memberikan informasi terkait bahaya penyalahgunaan narkotika yang pada gilirannya akan berkontribusi dalam memecahkan masalah darurat narkoba di Indonesia, dengan begitu, potensi penyalahgunaan dan peredaran narkotika akan dapat diminimalisir dan kemudian sedikit demi sedikit penyalahgunaan narkotika dan peredaran gelap narkotika akan teratasi dengan baik sehingga generasi muda bangsa ini akan terbebas dari narkotika dan memiliki karakter serta prestasi akademik yang baik.

\section{SIMPULAN}

Penggunaan internet tentang narkotika di kalangan siswa masih tergolong rendah. Siswa yang menggunakan fasilitas internet sebesar 24\% yang mengakses sebagai sarana belajar. Pencegahan narkotika melalui pemanfaaatan internet dapat dilakukan dengan mendorong siswa untuk lebih aktif mencari informasi tentang bahaya narkotika sehingga siswa memiliki pengetahuan moral mengenai narkotika. Peranan sekolah juga dibutuhkan untuk mencegah penyalahguna narkotika di kalangan siswa dengan mengadakan seminar atau penyuluhan tentang narkotika. Membatasi kebebasan siswa dalam pergaulan, menciptakan hubungan yang baik dengan siswa dan memberikan filter terhadap konten-konten internet yang kurang sesuai dengan kebudayaan lokal atau Indonesia dapat membantu mencegah penyalahguna narkotika di kalangan siswa.

\section{UCAPAN TERIMA KASIH}

Ucapan terima kasih kami ucapkan kepada DRPM Kemenristek Dikti berdasarkan Surat Keputusan Nomor 0045/E3/LL/2018 yang telah memberikan dukungan dana untuk penelitian ini. Terima kasih juga kami ucapkan kepada pihak yang telah membantu penelitian ini.

\section{DAFTAR PUSTAKA}

Anonim. (2011). Pedoman pelaksanaan pendidikan karakter. Jakarta: Badan Penelitian dan Pengembangan Pusat Kurikulum. 
Cahyo, D, E. (2017). Pendidikan karakter guna menanggulangi dekadensi moral yang terjadi pada siswa sekolah dasar. Eduhuamaniora: Jurnal Pendidikan Dasar, 9 (1), 14-26.

Carolyn, A, L., \& David J. Atkin. (2007). Communication technology and social Change: theory and implications. Lawrence Erlbaum Associates

http://www.emarketer.com. Largest countries of internet users. Diakses tanggal 18 Desember 2018.

Hastjarjo, S. (2011). New media teori dan aplikasi. Surakarta: Lindu Pustaka

Juliana L, F. (2013). Narkoba, psikotropika, dan gangguan jiwa. Yogyakarta: Nuha Medika

Marviana. (2000). Narkoba dan remaja. Jakarta: Gramedia

Muslich, M. (2011). Pendidikan karakter: menjawab tantangan multidimensional. Jakarta: Bumi Aksara.

Noviandari, L. (2015). Statistik pengguna internet dan media sosial terbaru 2015. Diakses 18 Januari 2019 dari techinasia: https://id.techinasia.com/

Shelyanita, A.S, \& Rakhmawati, A.N. (2016). Pengaruh dan pola aktivitas penggunaan internet serta media sosial pada siswa SMPN 52 Surabaya. Journal of Information System Engineering and Business Intelligences, 2(1), 17-22.

Siregar, A. (2004). Peranan strategis media massa dalam pembangunan jati diri bangsa: antara cita dan realita. Jakarta: Forum Diskusi Kebudayaan Bappenas.

Suharko. (2006). Gerakan sosial: konsep,strategi, aktor, hambatan dan tantangan gerakan sosial di Indonesia. Jakarta: Averroes Press. 